\title{
Pirandello y el pirandellismo
}

\section{I}

(1) LA vida de Pirandello conocemos pocos detalles. En un prólogo nos dice únicamente que ha nacido en Grigenti, el antiguo Agrigento; que en Bonn se doctoró en filosofía, y que ha estado más de veinte años de profesor en un colegio de niñas en Roma. Hoy, ya no da lecciones. Es miembro de la nueva Academia de Italia y posee un teatro en el cual hace representar sus piezas. ¿Su obra? Es innumerable, aunque en Francia no se conoce aún más que una pequeña parte (1). En sus novelas se revela como un escritor impregnado de un perfume regional. Ha descrito Sicilia con minuciosa exactitud. En La cartilla roja, primero, y en $L a$ excluida, después, estudia la tiranía de la opinión pública. En El extranjero (novela corta publicada por Les Annales de París, y luego en la colección Vieja Sicilia) volvemos a encontrar esa xenofobia que se puede comprobar desde el momento en que se aleja uno de los centros de turismo. En la misma colección tenemos el cuento intitulado Canta la epistola, en donde Pirandello muestra una filosofía poética y profundamente amarga a la vez. Así desearíanos ver tratada la rovela que nos ha anunciado sobre el destino del hombre, libro al que ha decidido consagrar los «diez últimos» años de su vida....

Pero lo que le hizo célebre fué la manera cómo renovó la cuestión de la personalidad, ya en su novela Alguien, nadie, cien mil hombres, que aun no se ha publicado en francés; ya en sus comedias, de las cuales ha sacado los argumentos de sus novelas cortas; comedias que, lanzadas por París, sorprendieron en un instante al mundo: A cada uno su verdad, que es, en nuestra opinión, su obra maestra y cuyo título es toda una filosofía. Seis personajes en busca de autor, esos confines de lo real, que Pitoeff supo hacer tan alucinantes. Vestir al desnudo, en donde la mentira viene a poner lín poco de poesía en torno de la verdadera vida. Enrique $I V$ y sus seductoras paradojas. Lo mejor posible (Todo por lo mejor), tan irónica con su piadosa y lastimera humanidad.

(1) Conviene advertir que en lengua española se han traducido casi todos los dramas y muchas colecciones de cuentos de Pirandello. M. Chassaigne podrá advertir que los lectores de habla española son más afortunados en este sentido que los de la francesa. (N. de la R.) 
¿Qué es, pues, el pirandellismo?

Segun nuestro entender, es la negación de toda realidad exterior; es el idealismo de Schopenhauer; es el syo espacial * de Bergson, puesto al alcance de las masas (y esto no es ahora tan fácil). Todo es subjetivo. Todo lo vemos a través de nosotros mismos.

Pero nosotros mismos somos mudables. $Y$ para tener una opinión, aun de sí mismo, es preciso tomar una forma... (una ilusión, una mentira). Los manuales de filosofía ya nos han puesto en guardia contra las dificultades y los peligros de la introspección. Estas dos proposiciones, viniendo después de la negación de toda trascendencia, lo conducen a uno al nihilismo.

En vano nos esforzaremos en escapar por la tangente, pretendiendo, verbi gratia, que cada forma ineluctable y necesaria, por el solo hecho de que nosotros la creamos real, es, efectivamente, real y viviente. El círculo no se vuelve a cerrar tan fácilmente. Este argumento no puede sino explicar la superficie de la vida, que oculta la nada. No puede hacer otra cosa más que comprender la existencia tenaz de nuestras ilusiones. Por eso es por lo que habiendo seguido a Pirandello hasta alli, hemos tenido que abandonarle cuando finge hallarse preso en sus propias redes. En Enrique IV, principalmente, Benjamín Cremieux, su inteligente traductor, ¿no trata de descubrir una parte constructiva? ¿Para qué construir? ¿Es lo mismo demoler que analizar?

\section{III}

En cuanto a la influencia de Pirandello en Europa, Evreinoff en Rusia, Leonardo Franck en Alemania y Andrés Wurmser en Francia parece que la han sufrido. Las letras españolas no han permanecido insensibles a la fuerte personalidad del escritor italiano.

La comedia de la dicha (La comedia de la felicidad), de Evreinoff, fué escrita, según parece, antes que los Seis personajes en busca de autor, pero sea como fuese, la semejanza del argumento es sorprendente. El mismo Pirandello ha reconocido el parentesco, puesto que la ha representado en su propio teatro. Los personajes interpretan sus papeles, no ya ante los espectadores sino entre ellos, no en el escenario sino en la vida real. 
Pero como cada uno de nosotros representamos un papel, ¿dónde está la ilusión? ¿Dónde la realidad?

Esta versión rusa es-hecho curioso-, más sencilla, más comprensible que la versión italiana. Sin embargo, el espíritu latino tiene fama por su claridad, mientras que el espiritu eslavo.... Verdad es que Evreinoff es hijo de una francesa.

En Karl y Anna, Leonardo Franck estudia un caso de desdoblamiento de la personalidad, pero quizá con más sobriedad aún. Dos soldados alemanes están prisioneros en Rusia; el uno está casado, el otro no. Pero este último ha oído hablar tanto de la mujer de su amigo y de su vida antes de la guerra, que la conoce tan bien como él, o quizá mejor. Habiendo logrado evadirse, se hace pasar ante Ana por su esposo. ¿Hasta qué punto se engañan el uno al otro?

Andrés Wurmser estudia a su vez la personalidad en una novela, Cambio de dueño: un hombre se halla de súbito transportado a otro cuerpo, en tanto que ve muerto su antiguo guiñapo. Es la historia de su adaptación a su nueva morada. ¿A quién ha sustituido? Volverse otro, iqué sueño! Pero cambiar de espíritu al mismo tiempo que de cuerpo....-L U I S C H A S S A G N E.

Exclusivo para Atenea en Chile.

\section{El héroe de la clase media en la novela chilena (1)}

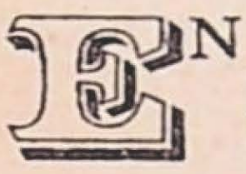

LA SEGUNDA mitad del siglo XIX nace a la vida literaria el héroe de la clase media, Martín Rivas. El propio autor de sus días extensos parece no concederle mayor importancia social. Los comentadores le ven moverse, por entre las páginas, como si fuera un personaje más de la serie blestganiana; un mortal humilde, oscuro, como tantos, que abandona la provincia para tentar fortuna en la capital. Nace en un lejano rincón provinciano, en un país convulsionado por las violencias del torbellino revolucionario y sujeto, como todos los hombres, a las alternativas indóciles del destino. Pero luego se hace comprensible su nacimiento en la voluntad del escritor. La adolescencia del creador de Martín Rivas se nutrió en el firme liberalismo de su padre, el Doctor Blest. El ambiente estaba impregnado

(1) Fragmento del ensayo en preparación Perspectiva de la novela y el cuento chilenos.

Atenea-5 